\title{
The effectiveness and safety of
} conservative interventions for positional plagiocephaly and congenital muscular torticollis: a synthesis of systematic reviews and guidance

\author{
Julie Ellwood ${ }^{1}$, Jerry Draper-Rodi ${ }^{1}$ and Dawn Carnes ${ }^{1,2^{*}}$
}

\begin{abstract}
Aim: To investigate for congenital muscular torticollis (CMT) and positional plagiocephaly (PP) the effectiveness and safety of manual therapy, repositioning and helmet therapy (PP only) using a systematic review of systematic reviews and national guidelines.

Methods: We searched four major relevant databases: PubMed, Embase, Cochrane and MANTIS for research studies published between the period 1999-2019. Inclusion criteria were systematic reviews that analysed results from multiple studies and guidelines that used evidence and expert opinion to recommend treatment and care approaches. Three reviewers independently selected articles by title, abstract and full paper review, and extracted data. Selected studies were described by two authors and assessed for quality. Where possible meta-analysed data for change in outcomes (range of movement and head shape) were extracted and qualitative conclusions were assessed.

Results: We found 10 systematic reviews for PP and 4 for CMT. One national guideline was found for each PP and CMT. For PP, manual therapy was found to be more effective than repositioning including tummy time (moderate to high evidence) but not better than helmet therapy (low evidence). Helmet therapy was better than usual care or repositioning (low evidence); and repositioning better than usual care (moderate to high evidence).

The results for CMT showed that manual therapy in the form of practitioner-led stretching had moderate favourable evidence for increased range of movement. Advice, guidance and parental support was recommended in all the guidance to reassure parents of the favourable trajectory and nature of these conditions over time.

\footnotetext{
* Correspondence: dawn.carnes@uco.ac.uk; dawn.carnes@hefr.ch

'University College Osteopathy, 275 Borough High St, London SE1 1JE, England

${ }^{2}$ Faculty of Health, University Applied Sciences and the Arts Western

Switzerland, Fribourg, Switzerland
}

(c) The Author(s). 2020 Open Access This article is licensed under a Creative Commons Attribution 4.0 International License, which permits use, sharing, adaptation, distribution and reproduction in any medium or format, as long as you give appropriate credit to the original author(s) and the source, provide a link to the Creative Commons licence, and indicate if changes were made. The images or other third party material in this article are included in the article's Creative Commons licence, unless indicated otherwise in a credit line to the material. If material is not included in the article's Creative Commons licence and your intended use is not permitted by statutory regulation or exceeds the permitted use, you will need to obtain permission directly from the copyright holder. To view a copy of this licence, visit http://creativecommons.org/licenses/by/4.0/. The Creative Commons Public Domain Dedication waiver (http://creativecommons.org/publicdomain/zero/1.0/) applies to the data made available in this article, unless otherwise stated in a credit line to the data. 


\begin{abstract}
(Continued from previous page)
Conclusions: Distinguishing between superiority of treatments was difficult due to the lack of standardised measurement systems, the variety of outcomes and limited high quality studies. More well powered effectiveness and efficacy studies are needed. However overall, advice and guidance on repositioning (including tummy-time) and practitioner-led stretching were low risk, potentially helpful and inexpensive interventions for parents to
\end{abstract} consider.

Systematic review registration number: PROSPERO 2019 CRD42019139074.

Keywords: Paediatric, Positional plagiocephaly, Congenital muscular torticollis, Systematic review

\section{Introduction}

Congenital muscular torticollis (CMT) is a postural, musculoskeletal deformity evident at, or shortly after, birth. It results from unilateral shortening and increased tone of the sternocleidomastoid (SCM) muscle and presents as lateral flexion of the head to the ipsilateral side with rotation to the contralateral side [1]. It is potentially a painful condition for infants and can present with a pseudotumor in the SCM muscle [2]. It is the third most common congenital musculoskeletal condition in newborns with an incidence ranging from 0.3 to $16 \%$ [3]. CMT has been associated with dysfunction in the upper cervical spine and is sometimes referred to as kinetic imbalance due to subocciptal strain (KISS) [2]. Treatment approaches for CMT include manual therapy (including practitioner-led stretching exercises) [4], repositioning therapy (including tummy time) [1] and, in severe nonresolving cases, botulinum and surgery [5]. CMT can lead to secondary changes such as cranial asymmetry, and also to functional problems, including breastfeeding problems [2].

Cranial asymmetry, also known as plagiocephaly, is the most common form of 'flat head syndrome' and presents itself as an asymmetrical head shape. Positional plagiocephaly (PP) (sometimes referred to as deformational plagiocephaly or non-synostotic plagiocephaly) typically occurs in infants and results from mechanical factors which, when applied over a period of time in utero, at birth, or postnatally, alter the shape of the skull [6]. In this condition there is flattening of one side of the occiput, with anterior displacement of the ipsilateral ear. The region of occipital flattening relates to the side that the head is toward when in the supine sleeping position [7].

A rise in the prevalence of PP occurred after widespread implementation in western countries of the 'Back to Sleep' campaigns which recommended that healthy term infants be positioned on their backs during sleep [8] to prevent Sudden Infant Death Syndrome (SIDS). Prior to 1992, the incidence of the deformity was estimated at 1 in 300 infants [9]. Estimates for PP prevalence now range from 16 to $48 \%$ of typical healthy infants younger than 1 year depending on the diagnostic criteria used and $37.8 \%$ for infants aged between 8 and 12 weeks old [10]. Considering this large increase in the incidence of PP, there has been much interest in investigating, managing, and preventing this condition [7]. Although the optimal timing and modality of interventions have yet to be clearly established, primary treatments for plagiocephaly are nonsurgical and include observation, head repositioning, manual therapy (including practitioner-led stretching exercises), and helmet therapy/orthotic devices [8].

Head repositioning therapy is usually performed by the parents with the purpose of positioning the infant's head on the non-flattened side and includes advice on 'tummy time' recommendations. Helmet therapy, sometimes referred to as orthotics or moulding therapy, generally uses a plastic helmet with the aim of reshaping the deformed skull to a normal shape without restricting the cranial growth $[11,12]$. Manual therapies such as that given by chiropractors, osteopaths, physiotherapists and physical therapists centre on techniques administered passively to the infant either through cervical articulation and soft tissue muscle stretching to restore neck function and/or soft tissue tension release/reduction [13]. Manual therapies also include practitioner-led stretching exercises, whether administered directly by a practitioner or by a practitioner guided parent.

The relationship between CMT and PP is slightly unusual as causality can go in either direction and infants can suffer from both conditions at the same time. There are similarities between the management strategies for both PP and CMT but limited research exists on their effectiveness. In addition, clear treatment protocols which take severity of the condition and age of the infant into consideration are lacking. There is concern about both CMT and PP due to their association with developmental dysplasia of the hip, brachial plexus injury, foot or lower limb anomalies and cognitive and motor development $[1,14]$.

\section{Aim}

To investigate for congenital muscular torticollis (CMT) and positional plagiocephaly (PP) the effectiveness and safety of manual therapy, repositioning and helmet therapy (PP only) using a systematic review of systematic reviews and national guidelines. 


\section{Methods}

We conducted a systematic review of systematic reviews and clinical guidelines for conventional treatments of both PP and CMT. We reviewed existing analyses of information whether it was based on compiled qualitative or narrative analyses, meta-analysis or guideline consensus review (PROSPERO registered number: CRD42019139074). We used the PRISMA statement to guide the structure of this review [15].

\section{Definitions and outcomes of interest Eligibility criteria}

We included reviews that reported a systematic review methodology with more than one reviewer indicated in the review process. Literature reviews and editorials were not included.

We included guidelines where clear methodological procedures for development were reported. The guidance needed to be developed from systematically designed evidence reviews and expert panel consensus. The guidance must be intended for broad use at a national level rather than intended as guidance for a single clinic, hospital or a specific setting. We excluded guidance targeted at parents.

Only systematic reviews and national guidelines published in English within the last 20 years (1999-2019) were reviewed. Details on the eligibility criteria in Table 1.

Positional plagiocephaly PP was defined as cranial asymmetry due to moulding and not to any other pathophysiological condition in infants who are otherwise healthy and thriving [3].

The outcomes of interest for PP were those reported in the included systematic reviews, including adverse events, for manual therapy (including practitioner-led stretching exercises), helmet therapy and repositioning therapy.

Congenital muscular torticollis CMT was defined as asymmetrical muscular tension in the neck causing directional head preference from birth but present in infants up to 1 year old who were otherwise healthy and thriving [11]. The outcomes of interest for CMT were those reported in the included systematic reviews for symmetry/range of movement and adverse events. Interventions of interest were manual therapy (including practitioner-led stretching exercises) and repositioning therapy (including 'tummy time').

We defined manual therapy as any predominantly touch-based therapy administered by a trained and registered manual therapist, such as a chiropractor, osteopath, osteopathic physician, physical therapist or physiotherapist. We also included practitioner-led stretching exercises, whether administered directly by the practitioner or by a practitioner guided parent in our definition.

\section{Information sources}

For systematic reviews we searched PubMed, MANTIS, Embase, and Cochrane databases. We searched the central clearing guideline database and known national health service centres for national guidelines developed for the treatment management and care of infants with $\mathrm{PP}$ and or CMT in English speaking countries (UK, Ireland, USA, Canada, Australia, New Zealand). The searches were conducted in June 2019 and we included all papers found from citation tracking up to this date.

\section{Search}

Key search terms were: infant*, paediatric, pediatric and 'nonsynostotic cranial deformity', 'nonsynostotic posterior plagiocephaly', 'positional plagiocephaly', 'congenital muscular torticollis', 'congenital torticollis' and Treatment, 'Manual therapy', osteopath", chiropract", physiotherap* and derivatives automated by the search engines. Search strings are shown in the Additional file 1.

\section{Study selection}

Results from searches on each database were downloaded into a reference management software: Endnote (version X4.0.2), and duplicates were removed. Titles and abstracts were screened by two independent researchers. Decisions of inclusion/exclusion of the articles were made in a meeting with the three authors to increase the consistency of the application of the inclusion and exclusion criteria. Citation tracking was used to triangulate our searches and check for missing reviews and guidance, as well as to identify other articles that may have not been indexed on PubMed. Full text papers were obtained for those that met the inclusion criteria and for those where it was unclear whether or not the abstract and title met the inclusion criteria. Inclusion and exclusion criteria were applied to all titles, abstracts and full papers. If more recent or updated version of guidelines than those gathered from the search were available, the more recent ones replaced those initially found.

Only guidance developed using clear methodological protocols for use at a national or international level were considered.

\section{Quality appraisal}

We appraised the quality of the systematic reviews using a modified version of the AMSTAR 2 critical appraisal tool [16]. We used AMSTAR guidelines and agreed on our modified tool in advance of quality appraisal. Of the 15 quality categories assessed, 8 were selected by the authors for the final calculation quality, we allocated a 
score of 1 for Yes, 0 for No and 0.5 for Partial Yes. Final scores for the quality assessment had a range from 0 to 8 ( 8 being highest quality). Each study was appraised by 2 independent reviewers and a third reviewer was used if mitigation was required (please see Additional file 2).

We reported on the quality of the guidelines reviewed by using a modified version of the AGREE II framework [17]. We used AGREE II guidelines and agreed on our modified tool in advance of quality appraisal. We reflected on the procedures for development of the guidelines and specifically whether they were consensus driven and/or evidence review driven. We adapted the AGREE II scoring system as some guideline groups have supporting methodological manuals as opposed to a methods section in their publications or included online as part of the clinical guidance. The AGREE II checklist has 23 items evaluating 6 domains. Where more than $75 \%$ of the 23 items (>17/23) were evaluated, considered and reported in the development of the guideline, we rated these as high-quality guidance. In guidance, where there was insufficient information to record a verdict, we left these domains blank. Guidelines of 16 or less domains did not receive an evaluation of high quality. Each guideline was appraised by one reviewer (please see Additional file 3 and 4).

\section{Data extraction and items}

We designed a form to extract systematic reviews' characteristics and data (see Tables 2 and 3). We summarised studies by type of intervention, number of studies included, number of participants, outcomes of interest and measure used. Where possible we extracted data on cranial asymmetry/head shape for PP and on passive cervical spine range of movement for CMT. We conducted a narrative synthesis review of outcomes where necessary and in the absence of synthesised data. We also extracted adverse event incident data and compared risk ratio between treatments where possible (see Tables 4 and 5).

One researcher independently extracted characteristics and data from the selected articles and a second reviewer checked the extraction. A third reviewer's opinion was sought in cases of disagreement in the extraction process.

\section{Level of evidence}

We used reported levels of evidence as published in the reviews and guidance and analysed these to indicate overall level of publication consensus on effectiveness and safety. The strength of the overall evidence was determined by the reviews and guidance evaluated as favourable, unfavourable or inconclusive with high, moderate or low certainty based on the quality of studies included.

\section{Results}

There were 232 studies selected for screening against title and abstract; of these 157 were for PP and 75 for CMT. Of the studies selected 140 were excluded leaving 92 for full paper review. A further 78 were excluded and 14 references were finally included in this systematic review. The final selection included 10 papers for PP and 4 for CMT. See Fig. 1.

There were 10 reviews in the final selection for positional plagiocephaly; 2 investigating effectiveness of manual therapy [8, 13], 3 for helmet therapy/orthotics [19, 21, 22], 1 for repositioning advice/therapy [18] and 4 papers which compared helmet therapy with repositioning $[7,11,20,23]$. All of these reviews conducted a narrative analysis of their results.

There were 4 CMT reviews in the final selection which examined the effectiveness of manual therapy $[10,20$, 23, 24]. However one review [24] searched for RCTs for Kinetic Imbalance for Sub-occipital Strain (KISS) syndrome which suggested that it is a component in both CMT and PP; they found no data to present on the treatment of this syndrome. Two of the reviews [10, 23] had data on one study only.

The characteristics of the final selection studies are shown in Tables 2 and 3.

\section{Outcomes}

There were no meta-analyses in any of the studies reviewed for PP, but two for manual therapy with CMT $[4,24]$.

\section{Positional plagiocephaly}

Six reviews reported on the effectiveness of helmet therapy for PP using a variety of methods for measuring cranial asymmetry. The control groups were either repositioning therapy or conservative care, where reported. The results in five out of the six reviews reported favourable outcomes for helmets but the quality of evidence was found to be low across all studies. Results of the reviews which reported on repositioning therapy were favourable in two studies when compared with usual care $[7,18]$ and unfavourable when compared with

Table 1 Eligibility criteria

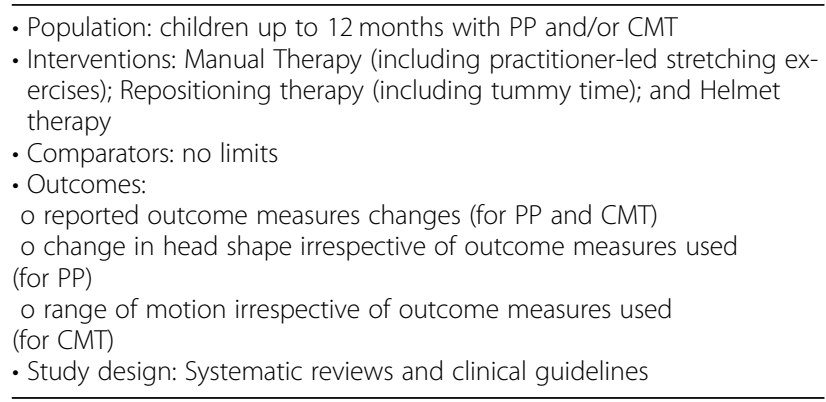


Table $\mathbf{2}$ Characteristics of systematic reviews on Plagiocephaly

\begin{tabular}{|c|c|c|c|c|c|}
\hline Authors & $\begin{array}{l}\text { Participants/n/age/gender/ } \\
\text { condition (where reported) }\end{array}$ & $\begin{array}{l}\text { Intervention } \\
\text { (Conservative- } \\
\text { repositioning, } \\
\text { helmet, MT) }\end{array}$ & $\begin{array}{l}\text { Timing of } \\
\text { intervention }\end{array}$ & $\begin{array}{l}\text { Number and type of studies } \\
\text { included in review }\end{array}$ & $\begin{array}{l}\text { Method of data } \\
\text { synthesis } \\
\text { (qualitative/ } \\
\text { meta-analysis) }\end{array}$ \\
\hline $\begin{array}{l}\text { Baird et al. } \\
2016[8]\end{array}$ & \multirow{3}{*}{$\begin{array}{l}\text { Paediatric (<18 years of age) } \\
\text { patients with non-synostotic } \\
\text { plagiocephaly or } \\
\text { brachycephaly. }\end{array}$} & Manual Therapy & NR & $3 / 2 \times R C T, 1 \times$ prospective & Narrative \\
\hline $\begin{array}{l}\text { Klimo et al. } \\
2016 \text { [18] }\end{array}$ & & Repositioning & NR & $\begin{array}{l}3 \text { RCT's (Class I), } 1 \text { prospective cohort study } \\
\text { (Class II), and } 6 \text { retrospective cohort studies } \\
\text { (Class III) }\end{array}$ & Narrative \\
\hline $\begin{array}{l}\text { Tamber et al. } \\
2016 \text { [19] }\end{array}$ & & Helmet therapy & NR & $\begin{array}{l}1 \text { prospective randomized controlled trial (Class } \\
\text { II), } 5 \text { prospective comparative studies, (Class II), } \\
\text { and } 9 \text { retrospective comparative studies (Class } \\
\text { II). }\end{array}$ & Narrative \\
\hline $\begin{array}{l}\text { Bialocerkowski } \\
\text { et al. } 2005 \text { [20] }\end{array}$ & Children $<12$ months/PP & $\begin{array}{l}\text { Positioning Vs } \\
\text { Helmet + Manual } \\
\text { therapy }\end{array}$ & NR & 16/ 12 case series, 4 comparative studies & Narrative \\
\hline $\begin{array}{l}\text { Goh et al. } \\
2013[21]\end{array}$ & Children/PP & Helmet therapy & NR & $\begin{array}{l}36 / 21 \text { were primary research literature articles, } \\
12 \text { reviews, } 2 \text { letters, } 1 \text { methodology descriptor }\end{array}$ & Narrative \\
\hline $\begin{array}{l}\text { McGarry et al. } \\
2008 \text { [22] }\end{array}$ & Infants/PP & Helmet therapy & NR & $\begin{array}{l}\text { 20/ } 3 \text { reviews, } 8 \text { measurement, } 9 \text { mixed } \\
\text { research method }\end{array}$ & Narrative \\
\hline $\begin{array}{l}\text { Paquereau, J. } \\
2013 \text { [23] }\end{array}$ & $\begin{array}{l}\text { Children }<18 \text { months } / n= \\
1724 \text { in original articles/PP }\end{array}$ & $\begin{array}{l}\text { Orthotics Vs } \\
\text { Repositioning }\end{array}$ & $\begin{array}{l}1-15 \\
\text { months }\end{array}$ & 18/ 6 literature reviews, 12 original articles & Narrative \\
\hline $\begin{array}{l}\text { Parnell Prevost } \\
\text { et al. } 2019 \text { [13] }\end{array}$ & $\begin{array}{l}\text { Infants/0-12 weeks/paediatric } \\
\text { conditions including cranial } \\
\text { asymmetry }\end{array}$ & Manual Therapy & NR & 50/ 32 RCT's and 18 Observational studies & Narrative \\
\hline $\begin{array}{l}\text { Shweikeh et al. } \\
2013 \text { [7] }\end{array}$ & Children 3-18mths/PP & $\begin{array}{l}\text { Repositioning Vs } \\
\text { Helmet Vs Manual } \\
\text { therapy }\end{array}$ & Long term & $\begin{array}{l}15 / 2 \text { RCT's, } 4 \text { case controls, } 4 \text { retrospective } \\
\text { studies, } 2 \text { prospective studies, } 2 \text { longitudinal, } 1 \\
\text { cross-sectional }\end{array}$ & Narrative \\
\hline $\begin{array}{l}\text { Xia et al. } 2008 \\
\text { [11] }\end{array}$ & $\begin{array}{l}\text { Healthy infants }<12 \text { months } \\
\text { with PP }\end{array}$ & $\begin{array}{l}\text { Moulding helmet } \\
\text { therapy vs head } \\
\text { repositioning } \\
\text { therapy }\end{array}$ & 6 months & 7 cohort studies & Narrative \\
\hline
\end{tabular}

manual therapy or helmet therapy [18]. These studies were graded as moderate to high quality where reported. Manual therapy produced favourable outcomes when compared with repositioning therapy or standard care $[8,13]$ but inconclusive findings when compared with helmet therapy [20]. The quality of the studies within these reviews varied. See Table 4.

\section{Congenital muscular torticollis}

Three reviews extracted data for the effectiveness of CMT treatments. One reported favourable results after 3 weeks of manual therapy (practitioner-led stretching) and the level of evidence was graded as moderate [25]. The two other reviews which reported on manual therapy for CMT each reviewed the same

Table 3 Characteristics of studies for Manual Therapy intervention for Congenital Muscular Torticollis

\begin{tabular}{|c|c|c|c|c|}
\hline Authors & Participants/n/age/gender/condition & Timing of intervention & $\begin{array}{l}\text { Number and type of studies } \\
\text { included in review }\end{array}$ & $\begin{array}{l}\text { Method of data synthesis } \\
\text { (narrative/meta-analysis) }\end{array}$ \\
\hline $\begin{array}{l}\text { Brand et al., } \\
2005[24]\end{array}$ & $\begin{array}{l}\text { Children 0-23 months/KISS with PP, } \\
\text { positional preference and infantile colic }\end{array}$ & NR & 2 RCT's & Meta-analysis \\
\hline $\begin{array}{l}\text { Driehuis et al., } \\
2019[4]\end{array}$ & $\begin{array}{l}\text { Infants and children/ paediatric } \\
\text { conditions including CMT }\end{array}$ & 8 weeks for CMT & $\begin{array}{l}26 / 12 \text { RCT's, } 9 \text { observational and } \\
5 \text { case reports } \\
1 \text { RCT related to CMT (Haugen } \\
\text { et al., 2011) }\end{array}$ & Meta-analysis \\
\hline $\begin{array}{l}\text { Heidenreich } \\
\text { et al., } 2018 \text { [25] }\end{array}$ & Infants and children/ CMT/ $<12$ months & $\begin{array}{l}3 \text { weeks with }<6- \\
\text { month FU where } \\
\text { reported }\end{array}$ & $\begin{array}{l}\text { 20/ } 10 \text { described/ } 4 \\
\text { retrospective cohorts, } 2 \text { Cohorts, } \\
4 \text { RCT's }\end{array}$ & Narrative \\
\hline $\begin{array}{l}\text { Parnell Prevost } \\
\text { et al., } 2019 \text { [13] }\end{array}$ & $\begin{array}{l}\text { Infants/0-12 weeks/paediatric conditions } \\
\text { including CMT }\end{array}$ & NR & $\begin{array}{l}\text { 50/ } 32 \text { RCT's and } 18 \\
\text { Observational } \\
1 \text { RCT related to CMT (Haugen } \\
\text { et al., 2011) }\end{array}$ & Narrative \\
\hline
\end{tabular}


Table 4 Summary of narrative analyses of treatments for Plagiocephaly

\begin{tabular}{|c|c|c|c|c|c|c|}
\hline Author & Vs Control & $\begin{array}{l}\text { Follow-up } \\
\text { time-point }\end{array}$ & $\begin{array}{l}\text { Cranial asymmetry - measurement } \\
\text { method }\end{array}$ & Effect & $\begin{array}{l}\text { Level of } \\
\text { evidence }\end{array}$ & Amstar \\
\hline \multicolumn{7}{|l|}{ Helmet therapy } \\
\hline $\begin{array}{l}\text { Goh et al. } 2013 \\
\text { [21] }\end{array}$ & NR & NR & Anthropometric assessment & Inconclusive & Low & 2 \\
\hline $\begin{array}{l}\text { McGarry et al. } \\
2008 \text { [22] }\end{array}$ & NR & $\begin{array}{l}\text { Up to } 13 \\
\text { months }\end{array}$ & $\begin{array}{l}\text { Bands, anthropometric callipers, moulding } \\
\text { ring, observation, photography }\end{array}$ & Favourable & Low & 4.5 \\
\hline $\begin{array}{l}\text { Paquereau et al. } \\
2013[23]\end{array}$ & Repositioning & & Cranial index, CVAl, 3D, visual & Favourable & Low & 3.5 \\
\hline $\begin{array}{l}\text { Shweikeh et al. } \\
2013[7]\end{array}$ & $\begin{array}{l}\text { Repositioning } \\
\text { and usual care }\end{array}$ & $\begin{array}{l}>12 \\
\text { months }\end{array}$ & NR & Favourable in older children & NR & 2 \\
\hline $\begin{array}{l}\text { Xia et al. } 2008 \\
\text { [11] }\end{array}$ & $\begin{array}{l}\text { Repositioning } \\
\text { only }\end{array}$ & 6 months & $\begin{array}{l}\text { NR (one study Helmet } \times 1.3 \text { greater than } \\
\text { repositioning) }\end{array}$ & Favourable & Low & 8 \\
\hline $\begin{array}{l}\text { Congress of } \\
\text { NSSR and EBG } \\
\text { Tamber et al. } 2016 \\
{[19]}\end{array}$ & $\begin{array}{l}\text { Conservative } \\
\text { care }\end{array}$ & $<7$ months & Anthropometry CVAI, 3D & $\begin{array}{l}\text { Favourable in mod-severe } \\
\text { cases or older children }\end{array}$ & Low & 7 \\
\hline \multicolumn{7}{|c|}{ Repositioning therapy } \\
\hline $\begin{array}{l}\text { Shweikeh et al. } \\
2013 \text { [7] }\end{array}$ & Usual care & $\begin{array}{l}<12 \\
\text { months }\end{array}$ & NR & Favourable & NR & 2 \\
\hline $\begin{array}{l}\text { Congress of } \\
\text { NSSR and EBG } \\
\text { Klimo et al. } 2016 \\
{[18]}\end{array}$ & Helmet & NR & $\begin{array}{l}\text { Cranial index, CVAl, photography, 3D } \\
\text { analysis, }\end{array}$ & Unfavourable & Moderate & 7 \\
\hline $\begin{array}{l}\text { Congress of } \\
\text { NSSR and EBG } \\
\text { Klimo et al. } 2016 \\
\text { [8] }\end{array}$ & Manual Therapy & NR & $\begin{array}{l}\text { Cranial index, CVAl, photography, 3D } \\
\text { analysis }\end{array}$ & Unfavourable & High & 7 \\
\hline $\begin{array}{l}\text { Congress of } \\
\text { NSSR and EBG } \\
\text { Klimo et al. } 2016 \\
\text { [8] }\end{array}$ & Usual care & NR & $\begin{array}{l}\text { Cranial index, CVAl, photography, 3D } \\
\text { analysis }\end{array}$ & Favourable & $\begin{array}{l}\text { Moderate } \\
\text { to high }\end{array}$ & 7 \\
\hline \multicolumn{7}{|l|}{ Manual therapy } \\
\hline $\begin{array}{l}\text { Bialocerkowski } \\
\text { et al. } 2005 \text { [20] }\end{array}$ & Helmet & & CVAl, parental perceptions & Inconclusive & Low & 7 \\
\hline $\begin{array}{l}\text { Parnell Prevost } \\
\text { et al. } 2019 \text { [13] }\end{array}$ & Standard care & 2 weeks & NR & Inconclusive favourable & Moderate & 7 \\
\hline $\begin{array}{l}\text { Congress of } \\
\text { NSSR and EBG } \\
\text { Baird et al. } 2016 \text { [8] }\end{array}$ & Positional advice & NR & Plagiocephalometry & Favourable & High & 7 \\
\hline $\begin{array}{l}\text { Congress of } \\
\text { NSSR and EBG } \\
\text { Baird et al. } 2016 \text { [8] }\end{array}$ & $\begin{array}{l}\text { Positioning } \\
\text { pillow }\end{array}$ & NR & Plagiocephalometry & Favourable & Moderate & 7 \\
\hline
\end{tabular}

pilot study for data extraction: both intervention and control groups received paediatric physiotherapy, and the intervention group received additional spinal mobilization treatment (SMT). Although both intervention and comparator were forms of manual therapy, there was no significant difference in the outcome of the group with SMT in addition to physiotherapy. The systematic reviews weighted the level of evidence differently, very low and moderate $[4,13]$. See Table 5 .

\section{Adverse events}

No adverse serious events were reported in any of the RCTs reviewed. However, 2 studies [4, 24] looked at adverse events in other types of studies and case report studies. Both found examples of serious adverse events. One case reported by Driehuis et al. (2019) described temporary quadriplegia following treatment in 4-monthold boy. The other case was reported in 2 studies [20, 23] which described death in a 3-month-old girl. While both of these adverse events were associated with 
Table 5 Summary of narrative analyses of treatments for Congenital Muscular Torticollis

\begin{tabular}{|c|c|c|c|c|c|c|}
\hline Author & $\begin{array}{l}\text { Follow-up } \\
\text { time-point }\end{array}$ & Intervention Vs Control & C. Sp. PROM & Effect & $\begin{array}{l}\text { Level of } \\
\text { evidence }\end{array}$ & Amstar \\
\hline \multicolumn{7}{|c|}{ Stretching Exercises } \\
\hline $\begin{array}{l}\text { Heidenreich } \\
\text { et al. } 2018 \\
\text { [25] }\end{array}$ & $\begin{array}{l}3 \text { weeks } \\
\text { where } \\
\text { reported }\end{array}$ & $\begin{array}{l}\text { Practitioner led stretching Vs } \\
\text { Mixed (not reported) }\end{array}$ & Narrative & Favourable & Moderate & 5 \\
\hline \multicolumn{7}{|l|}{ Manual therapy } \\
\hline $\begin{array}{l}\text { Brand et al. } \\
2005[24]\end{array}$ & 8 weeks & $\begin{array}{l}\text { No studies identified for CMT/ } \\
\text { Plagio/KISS }\end{array}$ & No data available & N/A & N/A & 3 \\
\hline $\begin{array}{l}\text { Driehuis et al., } \\
2019^{a}[4]\end{array}$ & 8 weeks & $\begin{array}{l}\text { Spinal mobilization + physical } \\
\text { therapy Vs physical therapy } \\
\text { only }\end{array}$ & $\begin{array}{l}\text { In both groups torticollis positively } \\
\text { changed (IV: } 80 \% \text { improvement, C: } \\
\text { 81.3\%). }\end{array}$ & $\begin{array}{l}\text { No significant } \\
\text { difference between } \\
\text { groups ( } p: 0.85 \text { ). }\end{array}$ & $\begin{array}{l}\text { Very low } \\
\text { quality }\end{array}$ & 8 \\
\hline $\begin{array}{l}\text { Parnell } \\
\text { Prevost et al. } \\
2019^{\mathrm{a}}[13]\end{array}$ & 8 weeks & $\begin{array}{l}\text { Manual Therapy + physio Vs } \\
\text { physio only }\end{array}$ & Narrative & $\begin{array}{l}\text { Inconclusive } \\
\text { (unfavourable) }\end{array}$ & Moderate & 7 \\
\hline
\end{tabular}

cervical spine manipulation for CMT in one study [23], the other study [20] associated the death with the administration of Vojta, a physiotherapy technique, for KISS. See Table 6.

\section{Guidance}

We found one guideline for positional plagiocephaly management that met our criteria and had a published guideline development procedure by the Congress of Neurological Surgeons Taskforce [26]. We were able to ascertain that it met at least 16 of the total AGREE II quality appraisal criteria (See Additional file 3). This guideline [27] was based on the systematic reviews by Klimo et al [22], Baird et al [5] and Tamber et al [21], all published in 2016 as part of the taskforce working group. The guideline recommended both physical therapy and repositioning as first line treatment followed by helmet therapy as a second line of treatment for infants with moderate to severe and persisting asymmetry. They recommended physical therapy above positioning pillows

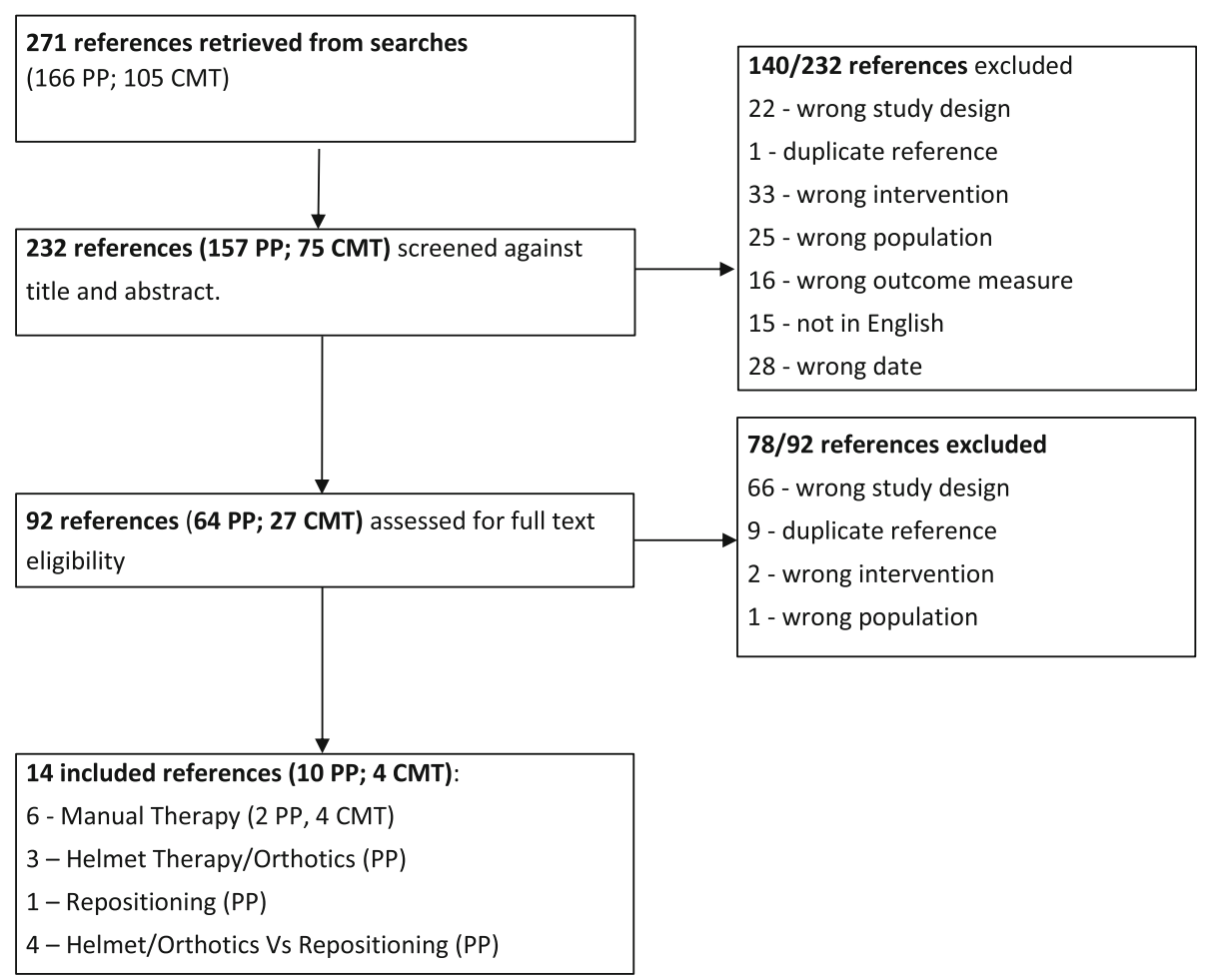

Fig. 1 Flowchart of search process for the review 
Table 6 Adverse event reporting

\begin{tabular}{|c|c|}
\hline Authors & Adverse Events reported \\
\hline \multicolumn{2}{|l|}{ Positional Plagiocephaly } \\
\hline Bialocerkowski et al. 2005 [20] & Not reported \\
\hline Goh et al. 2013 [21] & Not reported \\
\hline McGarry et al. 2008 [22] & $\begin{array}{l}\text { No serious harm was associated with cranial orthoses. Potential health risks such as skin } \\
\text { irritation and breakdown due to excessive pressure, and heat and perspiration were noted. } \\
\text { Occasional rashes on the infant's skin caused by heat or reaction to materials may occur. }\end{array}$ \\
\hline Paquereau et al. 2013 [23] & $\begin{array}{l}\text { Re-positioning pillows on a mattress reduce the free mobility of the cephalic extremity of the } \\
\text { infants. We must therefore wonder about the consequences of the restriction of these } \\
\text { spontaneous movements which could have a facilitating role in the onset of the sudden infant } \\
\text { death. The risk-benefit balance of the posterior positional plagiocephaly treatment should be } \\
\text { taken into account. }\end{array}$ \\
\hline Shweikeh et al. 2013 [7] & In the studies that reported adverse events, none were recorded. \\
\hline Xia et al. 2008 [11] & Not reported \\
\hline Parnell Prevost et al. 2019 [13] & None occurred in the RCTs. Not reported for observational studies \\
\hline $\begin{array}{l}\text { Congress of Neurological Surgeons Guideline: } \\
\text { Positional Plagiocephaly } 2016 \text { [26] }\end{array}$ & $\begin{array}{l}\text { Repositioning NR } \\
\text { Physical therapy NR } \\
\text { Helmet therapy NR }\end{array}$ \\
\hline \multicolumn{2}{|l|}{ CMT } \\
\hline Heidenreich et al. 2018 [25] & Not reported \\
\hline Parnell Prevost et al. 2019 [13] & The RCT included does not mention of adverse events. \\
\hline \multicolumn{2}{|l|}{ Mixed PP and CMT } \\
\hline Brand et al. 2005 [24] & $1 \times$ case report: $1 \times$ death following administration of Vojta therapy by physiotherapist for KISS \\
\hline Driehuis et al. 2019 [4] & $\begin{array}{l}2 \times \text { case reports: } 1 \times \text { temporary quadriplegia following cervical spine manipulation in 4-month- } \\
\text { old boy and } 1 \times \text { death following cervical spine manipulation in } 3 \text {-month-old girl. }\end{array}$ \\
\hline
\end{tabular}

due to the risk of Sudden Infant Death Syndrome [26]. See Table 7.

The national guidance for CMT by the American Physical Therapy Association met 21 of the 23 AGREE II quality criteria (See Additional file 4). The first line treatment recommendations were similar for both PP and CMT, i.e. parent education and support, positioning and tummy time, physical therapy including passive articulation and stretching. See Table 8.

Table 7 Summary Clinical Guideline recommendations for Positional Plagiocephaly

\begin{tabular}{ll}
\hline Recommendations & $\begin{array}{l}\text { World } \\
\text { Congress of Neurological } \\
\text { Surgeons 2016 }\end{array}$ \\
\hline Physiotherapy / Physical therapy & $\checkmark$ \\
Home exercise (e.g. passive stretching) & \\
Positioning (e.g. tummy time) & $\checkmark$ \\
Helmet/Orthotic therapy & $\checkmark$ \\
Repositioning pillow & $\checkmark$ \\
Education & $\checkmark$
\end{tabular}

a'World: Congress of Neurological Surgeons https://www.cns.org/sites/default/ files/guideline-pdf/summary_with_recommendations_final_12.1.16.pdf Joint Guidelines Committee of the American Association of Neurological Surgeons (AANS) and the Congress of Neurological Surgeons (CNS) and American Academy of Pediatrics (AAP)

\section{Discussion}

The results for treatments for PP indicated that repositioning therapy had moderate to high quality level of evidence showing a mix of favourable and inconclusive findings. Manual therapy interventions had moderate to high quality evidence showing favourable outcomes when compared with repositioning therapy and positioning pillows [8] but equivocal low-level evidence findings when compared with standard care and helmet therapy. Helmet therapy was favourable for head shape change but the quality of these studies was low, indicating that there was uncertainty around these findings. The effectiveness of helmet therapy compared to manual therapy was inconclusive [20].

The results for CMT showed that manual therapy in the form of practitioner-led stretching had moderate favourable evidence for increasing range of movement and there was low quality inconclusive evidence to support SMT in addition to physiotherapy. Caution is required when interpreting the evidence for manual therapy for CMT as it only relies on one underpowered pilot study with methods that were inappropriate to assess effectiveness [28].

It is a mixed and confusing batch of evidence which is compounded with poor standardisation of measurement 
Table 8 Summary Clinical Guideline recommendations congenital muscular torticollis

\begin{tabular}{ll}
\hline Recommendations & USA \\
& $\begin{array}{l}\text { American Physical Therapy } \\
\text { Association 2018 }\end{array}$ \\
\hline $\begin{array}{l}\text { Physiotherapy / Physical } \\
\text { therapy }\end{array}$ & $\checkmark$ \\
$\begin{array}{l}\text { Home exercise (eg passive } \\
\text { stretching) }\end{array}$ & $\checkmark$ \\
$\begin{array}{l}\text { Positioning (e.g. tummy } \\
\text { time) }\end{array}$ & $\checkmark$ \\
Handling / feeding & $\checkmark$ \\
Education & $\checkmark$ \\
Botulinum & N/A (consider specialist referral if no \\
& response to PT treatment) \\
Surgery & response to PT treatment)
\end{tabular}

aSA: American Physical Therapy Association (Kaplan et al.

2018) https://www.ncbi.nlm.nih.gov/pubmed/30277962

criteria for both PP and CMT and a lack of available guidance. The first line treatment recommended in the guidance reviewed for both PP and CMT were: parent education and support, positioning / tummy-time and physical therapy. Parent education and support centred on reassurance that in the majority of cases positional preference and head shape can resolve over time and may be helped with repositioning and physical therapy (all guidance). If the education and guidance centres on the premise of natural resolution, the foundation for arguments for any kind of treatment or intervention seems limited. However some concern has been raised about severe and moderate cranial asymmetry (positional plagiocephaly and brachycephaly) and later cognitive and academic outcomes: direct causality was not suggested, the authors postulated that moderate / severe PP could be a marker for developmental risk, meaning that those who develop plagiocephaly may be at risk of developmental problems [14]. This implies a greater need to standardise measurement and definitions of mild, moderate and severe PP to determine which babies may benefit from extra care, monitoring and treatment.

Repositioning (including tummy time) and stretching regimes make intuitive sense when considering a mechanistic explanatory model for a treatment intervention. They may also have a high placebo element of effect because the parents are able to play an active role in helping to resolve the baby's condition [24], This does not, however, negate the need of practitioner input as parents often require advice, guidance and support to understand how and when to do the stretching and repositioning. Potential problems identified with the home exercises, repositioning and tummy time included adherence and 'critical dose' needed to make a change. The clinician or therapist delivering advice, guidance and support to parents does not have to be limited to one profession, especially if this allows for more access to support, advice and care.

There were no serious adverse events documented in any RCTs included in the systematic reviews we reviewed for manual therapies, repositioning and helmets. One study mentioned serious adverse events reported in case studies but causality between the manipulation treatment and the adverse events were inconclusive [4]. Minor adverse events were noted with helmet therapy, such as some skin irritation and rashes which may affect comfort and the infants' tolerance to wearing the helmet. Given this information it seems sensible to consider conservative treatments as a first line option unless otherwise indicated.

There was also a suggested issue with positioning pillows and the potential associated risk of infants not sleeping on their back and sudden infant death syndrome. Several studies concluded that despite the moderate and favourable beneficial effects on head shape and symmetry with the use of positioning pillows, it did not outweigh the risk of sudden infant death syndrome [8, 24]. The Congress of Neurological Surgeons' guidance recommended that manual therapy and repositioning be used rather than positioning pillows [8].

A limitation of reviews of reviews is that many of the same studies are repeatedly analysed, however we were able to compare the interpretation of findings between the different authors using the same studies. We noted that the authors consistently identified issues with non-standardised diagnostic criteria to classify levels of severity of PP and CMT and how the outcomes were measured, for example cranial asymmetry and/or cervical range of movement. We did not analyse these factors in this review, nor did we consider treatments for more severe cases of PP and CMT when an infant has clinical development or thriving issues (rather than observable mild cosmetic issues) that may indicate surgical interventions or botulinum. In addition, we did not review studies to fully comprehend meaningful change to the infants and their parents.

A strength of this review was that we compared synthesised evidence with the guidance and we noted that guideline recommendations were not fully grounded in high quality favourable evidence. We would concur with others [24] that there is some favourable, albeit lowquality evidence, of some benefit for manual therapy in the form of practitioner-led stretching for CMT only and repositioning for both PP and CMT with no reported serious adverse events, warranting that these should be considered in the first instance.

Further research is needed to understand when, and if, to intervene and the optimal stages of interventions for 
what kind of benefit, risk or discomfort to the infants. At present there is not enough robust data or evidence to fully inform guideline development. The most comprehensive attempt by the Congress of Neurological Surgeons [26] illustrated what a difficult and varied task it was to develop the guidance. They did three different systematic reviews to try and fully comprehend the literature surrounding PP.

\section{Conclusions}

Manual therapy for PP showed favourable outcomes when compared with repositioning therapy but equivocal low-level evidence when compared with helmet therapy. The results for CMT showed that manual therapy in the form of practitioner-led stretching had moderate favourable evidence for increasing range of movement but this evidence only relies on one underpowered pilot study. More well powered effectiveness and efficacy studies are needed.

Distinguishing between superiority of treatments was difficult due to the lack of standardised measurement systems, the variety of outcomes and limited high quality studies. There is still a need to have an accepted classification system for diagnosing and describing grades of PP and CMT to fully investigate when and if therapy is warranted and what change is a meaningful change. The type of treatment appropriate for the infants and the duration and dose of treatment is yet to be clearly determined.

Overall physical therapy such as stretches and/or exercises, repositioning and tummy-time may benefit some infants. Education, guidance and support is likely to reassure and help parents. Advice and guidance can be given by a variety of health care professional's but clearly clinical training is necessary to ascertain whether the infants are healthy and thriving with no underlying pathologies before conservative approaches and/or treatments are recommended.

\section{Supplementary information}

Supplementary information accompanies this paper at https://doi.org/10. 1186/s12998-020-00321-w.

Additional file 1: Appendix 1. Search string examples

Additional file 2: Appendix 2. AMSTAR Quality Appraisal of Included Studies

Additional file 3: Appendix 3. Quality appraisal of guidance AGREE ॥ Score for PP

Additional file 4: Appendix 4. Quality appraisal of guidance AGREE ॥ Score for CMT

\section{Acknowledgements}

None.

Ethical approval and consent to participate Not applicable.

\section{Availability of supporting data}

Data sharing Full datasets, analyses and full searches are available on request from the corresponding author at Dawn.Carnes@uco.ac.uk.

\section{Authors' contributions}

DC conceptualised and designed the study, contributed to the data selection, extraction and analysis, drafted the initial manuscript, reviewed and revised the manuscript. JE managed the data, contributed to the data selection, extraction and analysis, reviewed and revised the manuscript. JDR contributed to the data selection, extraction and analysis, reviewed and revised the manuscript. All the authors approved the final manuscript as submitted and agree to be accountable for all aspects of the work.

\section{Funding}

This review was funded primarily by the Australian College of Chiropractic Paediatrics (ACCP) with part of the funding provided by the College of Chiropractic Paediatrics (CCP) neither were involved in the literature search, extraction data, analysis and synthesis.

Consent for publication

Not applicable.

\section{Competing interests}

The authors declare that they have no competing interests.

Received: 29 January 2020 Accepted: 12 May 2020

Published online: 11 June 2020

\section{References}

1. Kaplan SL, Coulter C, Sargent B. Physical therapy Management of Congenital Muscular Torticollis: a 2018 evidence-based clinical practice guideline from the APTA academy of pediatric physical therapy. Pediatr Phys Ther. 2018;30(4):240-90.

2. Siegenthaler MH. Pediatric patients in Swiss chiropractic clinics: a questionnaire survey. J Manip Physiol Ther. 2017;40(7):477-85.

3. Stellwagen $L$, Hubbard E, Chambers $C$, Jones KL. Torticollis, facial asymmetry and plagiocephaly in normal newborns. Arch Dis Child. 2008:93(10):827-31.

4. Driehuis F, Hoogeboom TJ, der Sanden MWG N-V, de Bie RA, Staal JB. Spinal manual therapy in infants, children and adolescents: A systematic review and meta-analysis on treatment indication, technique and outcomes. PLoS One. 2019;14(6):e0218940.

5. Limpaphayom N, Kohan E, Huser A, Michalska-Flynn M, Stewart S, Dobbs MB. Use of combined Botulinum toxin and physical therapy for treatment resistant congenital muscular torticollis. J Pediatr Orthop. 2019;39(5):e343-e8.

6. Rekate HL. Occipital plagiocephaly: a critical review of the literature. J Neurosurg. 1998:89(1):24-30.

7. Shweikeh F, Nuno M, Danielpour M, Krieger MD, Drazin D. Positional plagiocephaly: an analysis of the literature on the effectiveness of current guidelines. Neurosurg Focus. 2013;35(4):E1.

8. Baird LC, Klimo P Jr, Flannery AM, Bauer DF, Beier A, Durham S, et al. Congress of Neurological Surgeons systematic review and evidence-based guideline for the Management of Patients with Positional Plagiocephaly: the role of physical therapy. Neurosurgery. 2016;79(5):E630-E1.

9. Boere-Boonekamp MM, van der Linden-Kuiper LL. Positional preference: prevalence in infants and follow-up after two years. Pediatrics. 2001;107(2): 339-43.

10. Ballardini E, Sisti M, Basaglia N, Benedetto M, Baldan A, Borgna-Pignatti C, et al. Prevalence and characteristics of positional plagiocephaly in healthy full-term infants at 8-12 weeks of life. Eur J Pediatr. 2018:177(10):1547-54.

11. Xia JJ, Kennedy KA, Teichgraeber JF, Wu KQ, Baumgartner JB, Gateno J. Nonsurgical treatment of deformational plagiocephaly: a systematic review. Arch Pediatr Adolesc Med. 2008;162(8):719-27.

12. Hummel P, Fortado D. Impacting infant head shapes. Adv Neonatal Care. 2005;5(6):329-40.

13. Parnell Prevost C, Gleberzon B, Carleo B, Anderson K, Cark M, Pohlman KA. Manual therapy for the pediatric population: a systematic review. BMC Complement Altern Med. 2019;19(1):60.

14. Collett BR, Wallace ER, Kartin D, Cunningham ML, Speltz ML. Cognitive Outcomes and Positional Plagiocephaly. Pediatrics. 2019;143(2):e20182373.

15. Liberati A, Altman DG, Tetzlaff J, Mulrow C, Gotzsche PC, loannidis JP, et al. The PRISMA statement for reporting systematic reviews and meta-analyses 
of studies that evaluate healthcare interventions: explanation and elaboration. BMJ. 2009;339:b2700.

16. Shea BJ, Reeves BC, Wells G, Thuku M, Hamel C, Moran J, et al. AMSTAR 2: a critical appraisal tool for systematic reviews that include randomised or non-randomised studies of healthcare interventions, or both. BMJ. 2017;358: j4008.

17. Brouwers MC, Kho ME, Browman GP, Burgers JS, Cluzeau F, Feder G, et al. AGREE II: advancing guideline development, reporting, and evaluation in health care. Prev Med. 2010;51(5):421-4.

18. Klimo P Jr, Lingo PR, Baird LC, Bauer DF, Beier A, Durham S, et al. Congress of Neurological Surgeons systematic review and evidence-based guideline on the Management of Patients with Positional Plagiocephaly: the role of repositioning. Neurosurgery. 2016;79(5):E627-E9.

19. Tamber MS, Nikas D, Beier A, Baird LC, Bauer DF, Durham S, et al. Congress of Neurological Surgeons systematic review and evidence-based guideline on the role of cranial molding Orthosis (helmet) therapy for patients with positional Plagiocephaly. Neurosurgery. 2016;79(5):E632-E3.

20. Bialocerkowski AE, Vladusic SL, Howell SM. Conservative interventions for positional plagiocephaly: a systematic review. Dev Med Child Neurol. 2005; 47(8):563-70,

21. Goh JL, Bauer DF, Durham SR, Stotland MA. Orthotic (helmet) therapy in the treatment of plagiocephaly. Neurosurg Focus. 2013;35(4):E2

22. McGarry A, Dixon MT, Greig RJ, Hamilton DR, Sexton S, Smart H. Head shape measurement standards and cranial orthoses in the treatment of infants with deformational plagiocephaly. Dev Med Child Neurol. 2008;50(8):568-76.

23. Paquereau J. Non-surgical management of posterior positional plagiocephaly: orthotics versus repositioning. Ann Phys Rehabil Med. 2013; 56(3):231-49.

24. Brand PL, Engelbert RH, Helders PJ, Offringa M. Systematic review of the effects of therapy in infants with the KISS-syndrome (kinetic imbalance due to suboccipital strain). Ned Tijdschr Geneeskd. 2005;149(13):703-7.

25. Heidenreich E, Johnson R, Sargent B. Informing the update to the physical therapy Management of Congenital Muscular Torticollis Evidence-Based Clinical Practice Guideline. Pediatr Phys Ther. 2018;30(3):164-75.

26. Flannery AM, Tamber MS, Mazzola C, Klimo P Jr, Baird LC, Tyagi R, et al. Congress of Neurological Surgeons systematic review and evidence-based guidelines for the Management of Patients with Positional Plagiocephaly: executive summary. Neurosurgery. 2016;79(5):623-4.

27. Haugen EB, Benth J, Nakstad B. Manual therapy in infantile torticollis: a randomized, controlled pilot study. Acta Paediatr. 2011;100(5):687-90.

28. Vogel S, Draper-Rodi J. The importance of pilot studies, how to write them and what they mean. Int J of Ost Med. 2017;23:2-3.

\section{Publisher's Note}

Springer Nature remains neutral with regard to jurisdictional claims in published maps and institutional affiliations.

Ready to submit your research? Choose BMC and benefit from:

- fast, convenient online submission

- thorough peer review by experienced researchers in your field

- rapid publication on acceptance

- support for research data, including large and complex data types

- gold Open Access which fosters wider collaboration and increased citations

- maximum visibility for your research: over $100 \mathrm{M}$ website views per year

At $\mathrm{BMC}$, research is always in progress.

Learn more biomedcentral.com/submissions 